\title{
Subjective well-being in men and women during the COVID-19 lockdown: A structural model
}

\author{
Cecilia Mota González, ${ }^{1}$ Nazira Calleja ${ }^{2}$ Claudia Sánchez Bravo, ' María Eugenia Gómez López,' Jorge \\ Carreño Meléndez
}

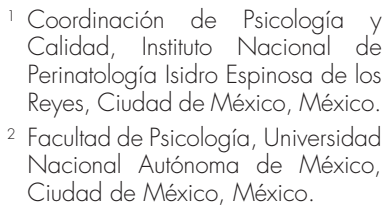

Correspondence:

María Eugenia Gómez López

Departamento de Psicología y

Calidad, Instituto Nacional de

Perinatología.

Torre de Investigación 1er. Piso,

Montes Urales 800

Lomas Virreyes,

11000 Alcaldía Miguel Hidalgo,

Ciudad de México México.

Phone: +52 (55) 3725-3723

Email: eugeniagomez2712@yahoo. com.mx

Received: 18 September 2020

Accepted: 15 February 2021

Citation:

Mota González, C., Calleja, N., Sánchez Bravo, C., Gómez López, M. E., \& Carreño Meléndez, J. (2021). Subjective well-being in men and women during the COVID-19 lockdown: A structural model. Salud Mental, 44(4), 201-209.

DOI: $10.17711 /$ SM.0185-3325.2021.026

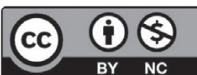

\begin{abstract}
Introduction. As a measure for controlling COVID-19, lockdown has had a psychological impact on people. Since subjective well-being (SW) has been positively associated with mental health, the identification of its predictors in this context will enable it to be strengthened. Objective. To generate and test explanatory models for SW in men and women under lockdown due to the pandemic. Method. Four thousand seven hundred and seventy-one inhabitants of Mexico, with paid employment, under lockdown, answered a set of instruments via the Internet that evaluated positive and negative psychological factors in addition to SW. Based on correlation and multiple regression analysis, models were proposed for men and women, which were tested by path analysis. Results. Both models successfully fit the data and explained a high proportion of the SW variance. Spiritual strength was the best predictor, mainly for women, while the capacity for enjoyment was central to the models, mediating the effect of empathy and depression. Discussion and conclusion. SW is significantly predicted by the factors studied, especially spiritual strength and capacity for enjoyment, which seem to provide men and women with fortitude and meaning of life in adverse circumstances such as today's.
\end{abstract}

Keywords: COVID-19, subjective well-being, spirituality, mental health.

\section{RESUMEN}

Introducción. El confinamiento, como medida de control para el COVID-19, ha tenido un impacto psicológico en las personas. El bienestar subjetivo (BS) se ha asociado positivamente con la salud mental, por lo que la identificación de sus predictores en el presente contexto permitirá su fortalecimiento. Objetivo. Generar y probar modelos explicativos del BS en mujeres y hombres confinados por la pandemia. Método. 4,771 habitantes de México, con empleo remunerado, en confinamiento, contestaron vía Internet una batería de instrumentos que evaluaban, además del BS, factores psicológicos positivos y negativos. A partir de un análisis de correlación y regresión múltiple, se propusieron modelos para mujeres y hombres, que se probaron mediante análisis de senderos. Resultados. Ambos modelos se ajustaron satisfactoriamente a los datos y explicaron una alta proporción de la varianza del BS. La fortaleza espiritual resultó el mejor predictor, principalmente para las mujeres; la capacidad de disfrute ocupó un lugar central en los modelos, mediando el efecto de la empatía y la depresión. Discusión y conclusión. El BS es predicho significativamente por los factores estudiados, en particular por la fortaleza espiritual y la capacidad de disfrute, que parecen aportar, a mujeres y hombres, entereza y sentido de vida en circunstancias adversas como la actual.

Palabras clave: COVID-19, bienestar subjetivo, espiritualidad, salud mental. 


\section{INTRODUCTION}

COVID-19 has forced millions of people worldwide into lockdown as a measure to prevent the transmission of the virus. Lockdown in Mexico began in March 2020, although it was not mandated as in other countries that imposed a curfew but voluntary, in keeping with the possibilities of the population. Even so, lockdown modified their routines and lifestyles.

Although this measure is effective in mitigating and controlling pandemics (Rodríguez-Morales et al., 2020; Vera-Villaroel, 2020), it entails psychosocial and economic costs that significantly impact the health and well-being of the population (Ferguson et al., 2020). During lockdown, emotional states drive people to engage in behaviors that jeopardize their health (Bults et al., 2011). Increases in depression, stress and anxiety have been documented in various countries, with differential effects between men and women (Mazza et al., 2020; Qiu et al., 2020; Sandín, Valiente, García-Escalera, \& Chorot, 2020; Wang et al., 2020). Ubillos Landa, González Castro, Puente Martínez, and Gracia Leiva (2020) note that during the first weeks of lockdown in Spain, women displayed more emotional symptoms (fear, anguish, pessimism, sadness, and hopelessness) than men. Conversely, in Mexico, men (university students) showed greater anxiety and stress (González-Jaimes, Tejeda-Alcántara, Espinosa-Méndez, \& Ontiveros-Hernández, 2020).

Although the effect of lockdown on psychopathology has recently been studied, some studies focus on positive emotional states, resilient traits, and quality of life. In China, Liu et al. (2020) found a negative relationship between happiness and life satisfaction, and anxiety and depression during the pandemic. Similar results were obtained by San Martín Ahumada (2020) in the Chilean population. In the study by Del Mar Molero et al. (2020), positive effects were associated with greater subjective well-being (SW) in men and women during lockdown.

SW is defined as the way in which people evaluate their satisfaction with their lives and the pleasant emotions they experience (Cuadra \& Florenzano, 2003), and is considered an indicator of mental health (Keyes, 2006). Its predictors in adverse contexts include health, money, and employment (Cajiao, Morales Arias, Garzón Romero, Benavides Basante, \& Acevedo Rincón, 2013), certain individual traits such as self-efficacy, extraversion, low neuroticism (Garaigordobil, Aliri, \& Fontaneda, 2009), a sense of humor, rejection and social distancing, and planning capacity (Ubillos Landa et al., 2020). González-Sanguino et al. (2020) observed that spirituality has been the main protective factor for mental health during the COVID-19 lockdown. Spiritual strength, understood as a feeling of harmony and peace, derived from a connection with something greater than oneself (Peterman, Fitchett, Brady, Hernandez, \& Cella, 2002), has been shown to mitigate suffering and contribute to overcoming adversity and coping with chronic diseases, encouraging acceptance and growth (Salgado, 2014), especially in times of crisis (Fardin, 2020). Although the number of Mexicans professing a religion has declined in recent years, for $84.4 \%$ (Instituto Nacional de Estadística y Geografía [INEGI], 2020), religious life is still of great importance. The degree of spiritual conviction, together with social support, helps people cope with adverse situations (Rivera-Ledesma \& Montero, 2005). During the pandemic, spirituality has been a source of comfort and strength for a large sector of the population (Gutiérrez Zúñiga \& de la Torre, 2020). Other individual traits that have not been studied in relation to lockdown, which could be associated with SW, are empathy, adaptability, and risk-taking.

In Mexico, mental health initiatives during the pandemic have been oriented, on the one hand, to informing and psychologically supporting the population with psychological care and crisis intervention programs, in both public health centers and institutions, which can be consulted on the website created by the federal government (coronavirus. gob.mx), and private mental health care centers (Gutiérrez Mercado, 2020; Esquivias Zavala et al., 2020), and on the other, to researching the effects of the pandemic and lockdown. In this regard, an increase in anxiety and stress has been found (Navarro Madera \& Becerra Castellón, 2020), together with domestic violence and fear of suffering from the disease (Morales Chainé et al., 2020). However, it is necessary to continue studying the emotional impact and intervening factors to ensure that the population maintains an optimal level of SW, which will enable it to cope with the current circumstances.

Accordingly, the purpose of this research was to produce and evaluate explanatory models of SW in men and women under lockdown during the COVID-19 pandemic. Possible predictors included positive psychological factors: spiritual strength, adaptability, empathy and the capacity for enjoyment, and negative factors: depressive symptoms, anxiety, stress, irritability, social rejection and risk taking, whose effect on SW has not been explored in lockdown situations. To obtain valid, reliable measurements of these variables, and as a complementary part of the proposed objective, the study aimed to obtain the psychometric indices of the instruments administered.

\section{METHOD}

\section{Study design}

This was a cross-sectional, quantitative, correlational study.

\section{Participants}

A sample of 4,771 subjects born and residing in Mexico. The majority were women $(75.8 \%, n=3,615)$, aged between 18 
and 77 , with a mean age of 38.94 years $(S D=10.96)$. Men, constituting $24.2 \%(n=1,156)$ of the sample, had a mean age of $40.15(S D=11.85)$, and an age range from 18 to 75 . The inclusion criteria were being of legal age, being engaged in paid employment and working from home, being under total or partial lockdown due to the COVID-19 epidemic, only leaving home for essential reasons and having an electronic device to answer the battery of instruments. Those who did not answer all the instruments were excluded from the study. Snowball sampling was used, with data being collected via the Internet from April 6 to 17, 2020.

\section{Measurements}

Sociodemographic data questionnaire. Information was collected on the region where the subjects lived, their nationality, age, sex, marital status, schooling, number of children, occupation, family support, and degree of lockdown.

Depression, Anxiety and Stress Scale, DASS-21. The short version adapted to Spanish by Román Mella, Vinet, and Alarcón Muñoz (2014) with three subscales with seven items each was administered. The authors reported acceptable fit indices in the confirmatory factor analysis (CFA) and $\alpha=.85$ (Depression), .72 (Anxiety), and .79 (Stress). Subjects were asked to answer based on their state of mind during lockdown using four response options ranging from It has not happened to me 1. to It has happened to me a lot 4. Examples of items include: "I have found it impossible to get excited about something" (Depression); "I have found it difficult to breathe" (Anxiety); "I have felt restless" (Stress).

Subjective Well-being Scale, EBS-8 (Calleja \& Mason, 2020). This scale evaluates SW in terms of life satisfaction and positive affect. It is one-dimensional, with eight items and six response options, ranging from Strongly disagree 1. to Strongly agree 6. Excellent fit indices were reported in its validation in the CFA and $\alpha=.968$. Examples of items include: "I am a happy person" and "I am satisfied with my life."

Spiritual Strength Questionnaire. Spiritual strength is defined as the connection with the transcendent dimension of life (Zinnbauer, Pargament, \& Scott, 1999). Three questions were developed to evaluate it: "My spiritual beliefs give my life meaning," "My spiritual beliefs give me peace," and "Difficult times have strengthened my spiritual beliefs." Likert-type response options were used, ranging from Strongly disagree 1. to Strongly agree 6. The internal consistency index was $\alpha=.950$.

Psychological Functioning Scale (PFS). Built for the study, based on the Ego Functions Assessment Scale (EFA), developed by Bellak and Goldsmith (1994), this scale assesses behavior through the mental examination of 12 functions, measured with open questions, within a clinical interview. The Mexican adaptation transformed it into a self-administered questionnaire, with Likert-type an- swers (Moral de la Rubia \& Meza Peña, 2012). The original questionnaire was developed through a process of observing symptoms and theoretical abstraction and did not follow a process of factorization nor was internal consistency calculated (Moral de la Rubia \& Meza Peña, 2012). To build the PFS, seven of the twelve functions of the EFA were selected, which are relevant for coping with crisis situations (Campuzano, 1987), and indicate the capacity for introspection of the subject, in such a manner that a person with adequate Ego functions will be well adapted to the environment, with the possibility of dealing adequately with obstacles. In contrast, a person in whom these functions are less developed will have a lower ability to cope with problems (Sosa Correa \& Duarte Briceño, 2004). The seven functions are object relations (five items), judgement (three items), regulation and control of instincts, affects, and impulses (four items), regression in the service of the ego (four items), defense function (four items), stimulus barrier (two items), and synthetic-integrative function (three items). The response options were Never 1. to Always 6. The instrument was subjected to the necessary psychometric process to obtain reliability and validity indices, which are reported in the Results section.

\section{Procedure}

The battery of instruments was prepared on the Google Forms platform, and a pilot study was undertaken. Twenty people who met the inclusion criteria for the sample were asked to fill in the form, and a telephone interview was conducted to ensure that the items had been understood and determine the ease of answering the questionnaire through electronic devices. The wording of certain items was adjusted and the number of items per screen in the form was modified so that they could be fully displayed on cell phones. The average time taken to answer the battery was 20 minutes. The instruments were disseminated via the Internet among people over 18 years old confined to their homes due to the pandemic. The context and objective of the study were explained at the outset and people were invited to answer the questionnaire after they had given their informed consent. Only those who met all the inclusion criteria were considered.

\section{Statistical analysis}

The Excel file provided by the Google Forms platform was transferred to an SPSS v. 22 file for data processing. For the PFS, an exploratory factor analysis (EFA) was conducted with the maximum likelihood method and Promax oblique rotation, using a random sample $(n=500)$ of the total number of subjects. The items associated with each factor with $\lambda$ $>.50$ were determined. The factor structures of all the scales were confirmed with CFA with random samples $(n=500)$; Cronbach's $\alpha$ internal consistency index was obtained for 
each one. The scores of the subscales were calculated using the means of the items comprising them.

Descriptive analyses and comparisons by sex of the variables studied were carried out with the Student's t test. Bivariate correlation and multiple linear regression analyses were made to identify the significant predictors of SW, which, in turn, were used to create the trail models to be tested to explain SW in men and women (Kline, 2015). Multivariate normality was verified through the Mardia coefficient; the estimation method was maximum likelihood.

The following indices were analyzed to determine the fit of the models (Hu \& Bentler, 1999): the $\chi^{2}$ goodness of fit test $\left(p>.05\right.$ indicates an adequate fit), the $\chi^{2} / \mathrm{gl}$ ratio $(<3)$, the Comparative Fit Index, CFI $(>.95)$, the Goodness of Fix Index, GFI $(>.90)$, the Standardized Root Mean Square Residual, SRMR $(<.05)$ and the Root Mean Square Error of Approximation RMSEA $(<.05)$. The suggested changes in the modification indices were made to improve the fit. The AMOS v. 22 program was used.

\section{Ethical considerations}

This research was approved by the Research and Ethics Committees of the Instituto Nacional de Perinatología, with registration number 2020-1-33.

\section{RESULTS}

\section{Psychometric analysis of scales}

The three-factor structure of the DASS-21 was confirmed with CFA, with five items with factor loadings $<.50$ and residual covariances $>2$ being eliminated. Satisfactory fit indices were obtained: $\chi^{2}{ }_{(95)}=271.854 ; \chi^{2} / \mathrm{gl}=2.862 ; \mathrm{CFI}=.974$; $\mathrm{NFI}=.961 ; \mathrm{GFI}=.953 ; \mathrm{SRMR}=.033 ; \mathrm{RMSEA}=.051, \mathrm{CI}$ $90[.044, .059]$. The internal consistency index $\alpha$ was .942 .

The CFA of the EBS- 8 yielded satisfactory fit indices: $\chi_{(16)}^{2}=28.502 ; \chi^{2} / \mathrm{gl}=1.781 ; \mathrm{CFI}=.997 ; \mathrm{NFI}=.992 ; \mathrm{GFI}=$ $.993 ; \mathrm{SRMR}=.012 ; \mathrm{RMSEA}=.040, \mathrm{CI} 90[.013, .063]$; and $\alpha=.956$ was obtained.

In the EFA of the PFS, the KMO coefficient was .872 and the Bartlett sphericity test was significant $p<.001$. Six factors were obtained, with 22 items, which explained $65.46 \%$ of the total variance. These measure: irritability (manifestation of impulses and difficulty tolerating frustration, for example, "Do you have outbursts of anger you cannot control?"), social rejection (withdrawal or distancing from others, such as "Do you feel you have no friends?"), risk-taking (lack of anticipation of consequences or foreseeing dangers, for example: "Do you do dangerous things?"), adaptability (ability to integrate contradictory or discrepant attitudes, affections, values, and behaviors, such as "Do you adapt easily to changes in routine?"), empathy (ability to discern the affective states of others and ease of communication with others, such as "Do you get personal satisfaction by helping others?") and capacity for enjoyment (ability to enjoy activities and personal interests and work routines, such as "Do you enjoy doing creative things?"). The factors were named differently from the original functions because the items were grouped differently in this adaptation of the instrument. The total internal consistency index was $\alpha=.821$. The CFA showed adequate levels of fit: $\chi^{2}{ }_{(193)}=499.602 ; \chi^{2}$ $\mathrm{gl}=2.589 ; \mathrm{CFI}=.947$; GFI $=.937$; $\mathrm{SRMR}=.063$; RMSEA $=.048$, CI $90[.043, .053]$, confirming the six-factor structure obtained in the EFA.

\section{Demographic characteristics of subjects}

Table 1 shows that the preponderant levels of educational achievement for men and women were undergraduate and graduate degrees. About half had a partner, and one in two had one or more children and lived mainly with their partner and offspring or with their parents and siblings. A higher percentage of men $(22.6 \%, n=261)$ than women $(16.5 \%, n=$

Table 1

Sociodemographic characteristics of subjects (percentages)

\begin{tabular}{|c|c|c|c|}
\hline Variable & Category & $\begin{array}{c}\text { Women } \\
(N=3615)\end{array}$ & $\begin{array}{c}\text { Men } \\
(N=1156)\end{array}$ \\
\hline \multirow{6}{*}{$\begin{array}{l}\text { Academic } \\
\text { level }\end{array}$} & Junior high school & .7 & 1.6 \\
\hline & Senior high school & 4.9 & 6.9 \\
\hline & Technical qualification & 4.7 & 4.1 \\
\hline & Bachelor's degree & 55.4 & 54.7 \\
\hline & Master's degree & 27.1 & 25.3 \\
\hline & Doctorate & 7.2 & 7.4 \\
\hline \multirow[t]{2}{*}{ Partner } & Yes & 48.9 & 46.6 \\
\hline & No & 51.1 & 53.4 \\
\hline \multirow[t]{2}{*}{ Offspring } & Yes & 52.6 & 50.2 \\
\hline & No & 47.4 & 49.8 \\
\hline \multirow{5}{*}{$\begin{array}{l}\text { Person } \\
\text { they live } \\
\text { with }\end{array}$} & Parents and siblings & 24.7 & 24.9 \\
\hline & Partner and offspring & 42.8 & 35.3 \\
\hline & Only with partner & 17.4 & 19.8 \\
\hline & Relatives and friends & 5.6 & 6.4 \\
\hline & Alone & 9.5 & 13.6 \\
\hline \multirow{3}{*}{$\begin{array}{l}\text { Maintaining } \\
\text { the family }\end{array}$} & Sole breadwinner & 16.5 & 26.2 \\
\hline & Is one of those who contribute & 63.0 & 55.0 \\
\hline & Does not support the family & 20.4 & 18.8 \\
\hline \multirow{2}{*}{$\begin{array}{l}\text { Social } \\
\text { security }\end{array}$} & Yes & 73.0 & 70.0 \\
\hline & No & 27.0 & 30.0 \\
\hline \multirow{4}{*}{$\begin{array}{l}\text { Part of the } \\
\text { country } \\
\text { they live in }\end{array}$} & North & 19.2 & 18.5 \\
\hline & West & 13.1 & 12.6 \\
\hline & Center & 60.4 & 59.1 \\
\hline & South & 7.3 & 9.7 \\
\hline \multirow{2}{*}{$\begin{array}{l}\text { Degree of } \\
\text { lockdown } \\
\text { during the } \\
\text { pandemic }\end{array}$} & Partial (essential trips) & 80.1 & 84.8 \\
\hline & $\begin{array}{l}\text { Total (did not leave the } \\
\text { house at all) }\end{array}$ & 19.9 & 15.2 \\
\hline
\end{tabular}


Table 2

Differences by sex in variables evaluated $\left(N_{M}=3615 ; N_{H}=1156\right)$

\begin{tabular}{llccc}
\hline $\begin{array}{l}\text { Psychological } \\
\text { factors }\end{array}$ & \multicolumn{1}{c}{ Variables } & $\begin{array}{c}\text { Women }(W) \\
\text { Mean* } \pm S D\end{array}$ & $\begin{array}{c}\text { Men }(M) \\
\text { Mean* } \pm S D\end{array}$ & $\begin{array}{c}\text { Statistical test } \\
t_{(4797)}\end{array}$ \\
\hline Positive & Subjective wellbeing & $4.79 \pm 1.20$ & $4.83 \pm 1.21$ & $.879, p>.05$ \\
& Spiritual strength & $4.06 \pm 1.66$ & $3.78 \pm 1.77$ & $4.961, p<.001$ \\
& Adaptation & $4.25 \pm 1.10$ & $4.03 \pm 1.19$ & $5.807, p<.001$ \\
& Empathy & $4.72 \pm 1.12$ & $4.40 \pm 1.29$ & $8.009, p<.001$ \\
& Capacity for enjoyment & $4.35 \pm 1.00$ & $4.32 \pm 1.08$ & $.800, p>.05$ \\
Negative & Depression & $1.63 \pm .67$ & $1.47 \pm .60$ & $6.993, p<.001$ \\
& Anxiety & $1.57 \pm .67$ & $1.34 \pm .54$ & $10.442, p<.001$ \\
& Stress & $2.02 \pm .76$ & $1.77 \pm .71$ & $9.823, p<.001$ \\
& Irritability & $2.54 \pm .99$ & $2.34 \pm .98$ & $6.048, p<.001$ \\
& Social rejection & $1.87 \pm .89$ & $1.88 \pm .94$ & $0.113, p>.05$ \\
& Risk-taking & $1.73 \pm .88$ & $2.03 \pm 1.01$ & $9.416, p<.001$ \\
\hline
\end{tabular}

Notes: *For SW, Spiritual Strength, Adaptation, Empathy and Capacity for Enjoyment: theoretical mean $=3.5$, range: 1-6; for Anxiety, Depression and Stress: Theoretical mean = 2.5: range: 1-4.

$596)$ were the sole breadwinner, while more women $(20.4 \%$, $n=737)$ than men $(18.8 \%, n=217)$, did not contribute financially to the family, although they were engaged in paid employment. Seven out of 10 had social security. Over half the sample lived in the center of the country (Mexico City, State of Mexico, Guerrero, Hidalgo, Morelos, Puebla, and Tlaxcala). At the time of answering the instruments, $19.9 \%$ $(n=719)$ of women and $15.2 \%(n=176)$ of men said they were under total lockdown. The remainder declared they were under partial lockdown, as they had to go out to make basic purchases or for medical consultations.

\section{Descriptive analysis and differences by sex}

\section{Positive psychological factors}

Table 2 shows the scores of SW, spiritual strength, adaptability, empathy, and capacity for enjoyment obtained by the subjects; the means of these variables were above the

Table 3

Bivariate correlation indices between study variables $\left(N_{M}=3615 ; N_{H}=1156\right)$

\begin{tabular}{|c|c|c|c|c|c|c|c|c|c|c|c|}
\hline Variables & Sex & 1 & 2 & 3 & 4 & 5 & 6 & 7 & 8 & 9 & 10 \\
\hline 1. Subjective well-being & & - & & & & & & & & & \\
\hline \multirow[t]{2}{*}{ 2. Spiritual strength } & Women & $.633^{*}$ & & & & & & & & & \\
\hline & Men & $.577^{\star}$ & - & & & & & & & & \\
\hline \multirow[t]{2}{*}{ 3. Adaptation } & Women & $.392^{*}$ & $.274^{*}$ & & & & & & & & \\
\hline & Men & $.289^{*}$ & $.236^{*}$ & - & & & & & & & \\
\hline \multirow[t]{2}{*}{ 4. Empathy } & Women & $.314^{*}$ & $.194^{*}$ & $.389^{*}$ & & & & & & & \\
\hline & Men & $.293^{*}$ & .116 & $.415^{\star}$ & - & & & & & & \\
\hline \multirow[t]{2}{*}{ 5. Capacity for enjoyment } & Women & $.446^{*}$ & $.246^{*}$ & $.598^{*}$ & $.468^{*}$ & & & & & & \\
\hline & Men & $.429^{\star}$ & $.201^{*}$ & $.615^{*}$ & $.525^{*}$ & - & & & & & \\
\hline \multirow[t]{2}{*}{ 6. Depression } & Women & $-.343^{*}$ & $-.222^{*}$ & $-.250^{*}$ & -.043 & $-.263^{*}$ & & & & & \\
\hline & Men & $-.338^{*}$ & $-.257^{*}$ & $-.213^{*}$ & -.033 & $-.196^{*}$ & - & & & & \\
\hline \multirow[t]{2}{*}{ 7. Anxiety } & Women & $-.197^{*}$ & -.084 & $-.140^{*}$ & .001 & $-.202^{*}$ & $.713^{*}$ & & & & \\
\hline & Men & $-.157^{*}$ & -.047 & -.082 & .010 & $-.117^{*}$ & $.578^{*}$ & - & & & \\
\hline \multirow[t]{2}{*}{ 8. Stress } & Women & $-.219^{*}$ & $-.156^{*}$ & $-.183^{*}$ & .023 & $-.212^{*}$ & $.732^{*}$ & $.714^{*}$ & & & \\
\hline & Men & $-.199^{*}$ & $-.152^{*}$ & $-.161^{*}$ & .051 & $-.175^{*}$ & $.680^{*}$ & $.641^{*}$ & - & & \\
\hline \multirow[t]{2}{*}{ 9. Irritability } & Women & $-.203^{*}$ & $-.155^{*}$ & $-.157^{*}$ & .029 & $-.128^{*}$ & $.502^{*}$ & $.470^{*}$ & $.519^{*}$ & & \\
\hline & Men & $-.179^{*}$ & $-.174^{*}$ & -.108 & .094 & -.085 & $.449^{*}$ & $.524^{*}$ & $.524^{\star}$ & - & \\
\hline \multirow[t]{2}{*}{ 10. Social rejection } & Women & $-.243^{*}$ & $-.174^{*}$ & $-.166^{*}$ & -.065 & $-.192^{*}$ & $.358^{*}$ & $.237^{*}$ & $.241^{*}$ & $.399^{*}$ & \\
\hline & Men & $-.175^{*}$ & $-.205^{\star}$ & $-.208^{*}$ & -.064 & $-.180^{*}$ & $.410^{*}$ & $.283^{*}$ & $.329^{*}$ & $.418^{*}$ & - \\
\hline \multirow[t]{2}{*}{ 11. Risk taking } & Women & -.071 & -.075 & -.054 & .033 & -.054 & $.180^{*}$ & $.173^{*}$ & $.183^{*}$ & $.278^{*}$ & $.249^{*}$ \\
\hline & Men & -.094 & $-.153^{*}$ & -.061 & $.119^{*}$ & .022 & $.215^{*}$ & $.159^{*}$ & $.224^{*}$ & $.304^{*}$ & $.227^{*}$ \\
\hline
\end{tabular}

${ }^{*} p<.001$. 
Table 4

Subjective well-being predictors obtained in multiple regression analysis for men and women participating in the study

\begin{tabular}{|c|c|c|c|c|c|c|c|}
\hline \multirow[b]{2}{*}{ Predictors } & \multirow[b]{2}{*}{ Sex } & \multicolumn{6}{|c|}{ Confidence interval 95\% } \\
\hline & & Beta & $\begin{array}{c}\text { Beta } \\
\text { standard }\end{array}$ & $\begin{array}{c}\text { Lower } \\
\text { limit }\end{array}$ & $\begin{array}{c}\text { Upper } \\
\text { limit }\end{array}$ & $t$ & $p$ \\
\hline \multirow[t]{2}{*}{ Constant } & $M$ & 2.860 & & 2.661 & 3.059 & 28.155 & $<.001$ \\
\hline & $\mathrm{H}$ & 3.103 & & 2.774 & 3.431 & 8.816 & $<.001$ \\
\hline \multirow[t]{2}{*}{ Spiritual strength } & M & .308 & .425 & .290 & .326 & 33.417 & $<.001$ \\
\hline & $\mathrm{H}$ & .265 & .390 & .234 & .297 & 14.170 & $<.001$ \\
\hline \multirow[t]{2}{*}{ Capacity for enjoyment } & M & .242 & .202 & .209 & .275 & 14.412 & $<.001$ \\
\hline & $\mathrm{H}$ & .266 & .237 & .206 & .325 & 2.683 & $<.001$ \\
\hline \multirow[t]{2}{*}{ Empathy } & $M$ & .111 & .103 & .083 & .139 & 7.765 & $<.001$ \\
\hline & $\mathrm{H}$ & .079 & .084 & .030 & .127 & 6.515 & $<.001$ \\
\hline \multirow[t]{2}{*}{ Depression } & $M$ & -.432 & -.242 & -.480 & -.384 & 17.586 & $<.001$ \\
\hline & $\mathrm{H}$ & -.528 & -.263 & -.627 & -.428 & 5.042 & $<.001$ \\
\hline \multirow[t]{2}{*}{ Social Rejection } & M & -.098 & -.073 & -.133 & -.063 & 5.522 & $<.001$ \\
\hline & $\mathrm{H}$ & .006 & .004 & -.056 & .067 & 2.389 & $>.05$ \\
\hline
\end{tabular}

theoretical mean. Men and women did not differ as regards SW or the capacity for enjoyment, while women scored significantly higher than men in empathy, spiritual strength, and adaptability.

\section{Negative psychological factors}

The mean scores of women for depressive symptoms, anxiety, stress, and irritability were significantly higher than those of men, who scored higher in risk taking. No differences were found by sex in social rejection. In general, scores were below the theoretical mean.

\section{Correlation analysis and multiple regression}

Significant correlation indices were obtained for all the variables with SW, except for risk-taking, whose indices were close to zero, in both men and women. The highest positive correlations were observed with spiritual strength and the capacity for enjoyment, and the highest negative ones with depression symptoms and stress (Table 3). High correlations $(>.70$ in women and $>.57$ in men) were observed between depression symptoms, anxiety, and stress; and between the latter and irritability $(>.40)$. Similar results were obtained with adaptability, empathy, and enjoyment capacity, which correlated moderately with each other, in men and women.

SW predictors were obtained through multiple regression analysis from the correlations. Risk-taking and anxiety were not significant and were excluded from the models. Stress, irritability and adaptability were also eliminated because they were multicollinear, which was quantified and tested with the indices obtained for tolerance $(<1)$ and variance inflation (VIF $>1$ ). The final model for women explained $48.2 \%$ of the variance in SW, whereas for men it explained $41.8 \%$, both of which were statistically signif- icant, with $\mathrm{F}(5,3609)=673.663, p<.001$ and $\mathrm{F}(5,1150)$ $=166.612, p<.001$, respectively. The predictors of the regression model for women were (Table 4) spiritual strength, depressive symptoms, capacity for enjoyment, stress, and social rejection, whereas for men, only the first four were significant.

\section{Pathway model}

Based on the regression analyses, explanatory pathway models of SW were proposed and tested, with the five predictors for women and four for men (without social rejection).

At the outset, multivariate normality was tested, with the Mardia coefficients obtained being 10.751 for women and 19.196 for men. The models are shown in Figure 1. All the regression weights were highly significant $(p<.001)$, and the fit indices of both models exceeded the cut-off points proposed by $\mathrm{Hu}$ and Bentler (1999). In the case of women, the standardized regression weight of social rejection was extremely low (-.05), and its elimination did not affect the remaining indices. The explained variance of SW based on the factors included was higher $(52.1 \%)$ in the women's than the men's model (42.3\%) and, although spiritual strength was the main predictor of SW in both cases, the standardized regression weight was higher in women (.52) than in men (.39). The capacity for enjoyment occupied a central place in both models, since it mediated the effect of spiritual strength, empathy, and depressive symptoms regarding SW, and was positively associated with empathy (which was also related to spiritual strength, mainly in the women's model) and negatively associated with depression symptoms. The latter were stronger predictors of SW in the case of men (-.26), than women (-.16), and more highly affected by spiritual strength $(-.28)$ in men than women $(-.22)$. 

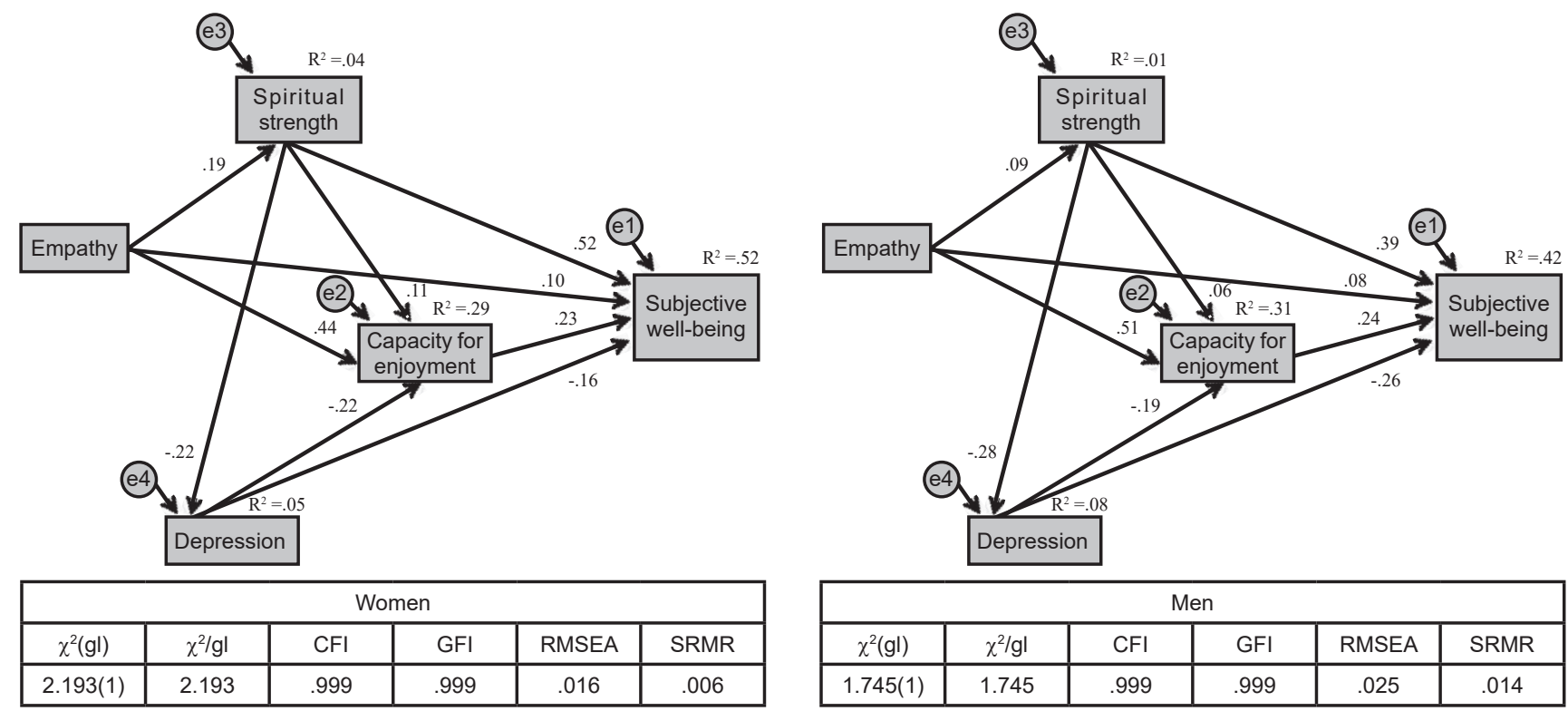

Note: Cut-off criteria for fitness indices of models: Coefficient $\chi^{2} / g I<3$ (CMIN/DF) < 3; CFI (Comparative Fit Index) > .95; GFI (Goodness of Fit Index) > .90; RMSEA (Root Mean Square Error of Approximation) < .05; SRMR (Standardized Root Mean Square of Residual) < .06 (Hu \& Bentler, 1999).

Figure 1. Pathway models of Subjective Wellbeing for men and women in the context of the COVID-19 pandemic.

\section{DISCUSSION AND CONCLUSION}

The main objective of this research was to generate and test explanatory models of SW in men and women during the COVID-19 lockdown. This was carried out to determine the positive and negative psychological factors that predict it for which separate models were created for each sex. First, it was found that the variables included explained a high percentage of the variance of SW in women (52\%), as opposed to $42 \%$ in men, suggesting that there are other unmeasured variables that explain SW in them.

Given that lockdown highlights the fragility, limitation, and vulnerability of human beings (San Martín Ahumada, 2020), spiritual strength was strongly associated with SW in both models, perhaps because it contributes internal resources that provide strength, creativity, humanity, or meaning of life, which can be useful in adverse situations. Spirituality enhances the ability to cope with situations of illness, disability, and negative life events (Landa Blanco, Landa Blanco, \& Cruz Murcia, 2018). However, it was observed that spiritual strength was more strongly associated with SW in women, which agrees with other studies showing that, when faced with critical events, women display more interpersonal strengths and spirituality, since they have a greater ability to connect with themselves, others, nature, God, or a higher reality, while men possess greater intellectual strength (Ovejero Bruna \& Cardenal Hernáez, 2015).

In keeping with the statement that joy is related to SW (Ryan \& Deci, 2001), in both models, the capacity for enjoyment mediated the effect of spiritual strength, empathy, and depressive symptoms on SW, such that those who had higher scores in spiritual strength and empathy, as well as fewer depressive symptoms, reported a greater capacity for enjoyment and SW. Other studies have also shown that empathy contributes to greater self-esteem, associated with more spirituality and life satisfaction (Kelm, Womer, Walter, \& Feudtner, 2014). It was observed that empathy is equally important for men and women as regards the capacity for enjoyment, even though various studies report that this trait is associated more with women (Guzmán Bohórquez, Duarte Ramos, \& Giraldo Camacho, 2019; Retuerto Pastor, 2004). Apparently, understanding the other in an unprecedented world situation sets in motion adaptive resources for coping better with the crisis (Johnson, Saletti-Cuesta, \& Tumas, 2020).

Regarding negative factors, depressive symptoms also contributed to explaining SW, although they were more strongly associated with SW in men. However, unlike what was reported by Nguyen et al. (2020), depression symptom scores were below the theoretical mean, possibly because during the data collection stage (at the beginning of phase 2 ), the number of COVID-19 patients and deaths was still low, meaning that people's emotional state had hardly been affected. However, the negative relationship observed in the model between spiritual strength and depression symptoms in men and women agrees with the findings of Salgado (2014), which indicate that spiritual strength serves as a mechanism for finding meaning in adverse situations, based on a belief system that is useful for coping with depression and stress, which is a protective factor against the 
psychological impact of this pandemic (González-Sanguino et al., 2020).

These results point to the need for a more in-depth study in future research of the role of these and other variables in the SW of men and women and of whether depression, anxiety, and stress are conditions caused or exacerbated by lockdown, since data were not collected on the subjects' previous mental health status. It is also suggested that studies be conducted on all phases of the pandemic. One of the limitations of the study was that data were only collected at the beginning of the second phase, meaning that the results obtained could vary at other times. Another constraint on generalization is that, although this was a large sample, it comprised mainly women, which could be due to their greater willingness to participate in self-report studies. Moreover, since the data were collected by electronic means, the sample comprised people who had access to technology, high educational attainment, and a steady income. Given that $41.9 \%$ of the population in Mexico are lagging educationally and lack access to social security, education, food, and decent housing, the model will probably have to be modified to incorporate samples with these sociodemographic characteristics.

A further limitation was that although the lockdown period was explored, it is impossible to guarantee a lack of bias in the subjects' answers.

Finally, this research made it possible to obtain the psychometric indices of the instruments administered to evaluate the factors considered in SW. Since they are reliable, valid instruments, they can be used in future research in which these psychological factors will have to be measured.

In conclusion, this study explains the variables that affect SW in men and women in the COVID-19 lockdown. Since SW is as an indicator of mental health, these results could contribute to the development of strategies that will reduce the impact of lockdowns and encourage the return to everyday life after the pandemic.

\section{Funding}

None.

\section{Conflict of interest}

The authors declare they have no conflicts of interest.

\section{Acknowledgments}

We would like to thank the Isidro Espinosa de los Reyes National Institute of Perinatology (INP, Instituto Nacional de Perinatología Isidro Espinosa de los Reyes) for his support in undertaking this research.

\section{REFERENCES}

Bellak, L., \& Goldsmith, L. A. (1994). Evaluación de las funciones del yo. México: Manual Moderno.

Bults, M., Beaujean, D. J., de Zwart, O., Kok, G., van Empelen, P., van Steenbergen, J. E., ... Voeten, H. A. (2011). Perceived risk, anxiety, and behavioural responses of the general public during the early phase of the Influenza A (H1N1) pandemic in the Netherlands: results of three consecutive online surveys. BMC Public Health, 11, 2. doi: 10.1186/1471-2458-11-2

Cajiao, G., Morales Arias, D. L., Garzón Romero, G. C., Benavides Basante, L., \& Acevedo Rincón, J. L. (2013). Revisión de algunos avances en la literatura sobre variables predictoras concernientes al "bienestar subjetivo". Cuadernos Hispanoamericanos de Psicología, 13(1), 45-62. Retrieved from: https:// dialnet.unirioja.es/servlet/articulo? codigo $=5493078$

Calleja, N., \& Mason, T. A. (2020). Escala de Bienestar Subjetivo (EBS-20 y EBS-8): Construcción y Validación. Revista Iberoamericana de Diagnóstico y Evaluación - e Avaliação Psicológica, 2(55), 185-201. doi: 10.21865/ridep55.2.14

Campuzano, M. (1987). Breve interludio teórico. In Los desastres naturales y sus repercusiones psicológicas. In Campuzano, M., Carrillo, J. A., Díaz Portillo, I., Döring, R., Dupont, M. A., Islas Mendizábal, L., \& Tubert, J. Psicología para casos de desastre (pp. 45-70). México: Pax-México. Retrieved from http:// cidbimena.desastres.hn/docum/crid/Marzo2004/pdf/spa/doc1030/doc1030contenido.pdf

Cuadra, H. L., \& Florenzano, R. U. (2003). El bienestar subjetivo: Hacia una psicología positiva. Revista de Psicología de la Universidad de Chile, 12(1), 83-96. doi: 10.5354/0719-0581.2003.17380

Del Mar Molero, M., Pérez Fuentes, M., Soriano, J. G., Oropesa, N. F., del Mar Simón, M., Sisto, M., \& Gázquez, J. J. (2020). Factores psicológicos en situaciones de cuarentena: Una revisión sistemática. European Journal of Health Research, 6(1), 109-120. doi: 10.30552/ejhr.v6i1.206

Esquivias Zavala, H., Andrade Pineda, C., Vieyra Ramos, V., Neria Mejía, R., Merlín García, I., Álvarez Martínez, J., \& Bezanilla, J. M. (2020). Manual Operativo del Taller Emergente para la Brigada de la atención psicoemocional y psicosocial a distancia durante la pandemia de COVID-19 en México (pp. 1-56). Retrieved from https://www.researchgate.net/publication/342343257_Manual_operativo_ del_Taller_Emergente_para_la_Brigada_de_Atencion_Psicoemocional_y_ Psicosocial_a_distancia_durante_la_pandemia_de_la_COVID-19_en_Mexico

Fardin, M. A. (2020). COVID-19 Epidemic and Spirituality: A Review of the Benefits of Religion in Times of Crisis. Jundishapur Journal of Chronic Disease Care, 9(2), 1-4. doi: 10.5812/jjcdc. 104260

Ferguson, N., Laydon, D., Nedjati Gilani, G., Imai, N., Ainslie, K., Baguelin, M., ... Ghani, A. (2020). Report 9: Impact of non-pharmaceutical interventions (NPIs) to reduce COVID19 mortality and healthcare demand. Imperial College London. Advance Publication Online. 1-20. doi: 10.25561/77482

Garaigordobil, M., Aliri, J., \& Fontaneda, I. (2009). Bienestar psicológico subjetivo: diferencias de sexo, relaciones con dimensiones de personalidad y variables predictoras. Psicología conductual, 17(3), 543-559. Retrieved from https://www.behavioralpsycho.com/wp-content/uploads/2020/04/07. Garaigordobil_17-3oa.pdf

González-Jaimes, N. L., Tejeda-Alcántara, A. A., Espinosa-Méndez, C. M., \& Ontiveros-Hernández, Z. O. (2020). Impacto psicológico en estudiantes universitarios mexicanos por confinamiento durante la pandemia por Covid-19. SciELO Preprints, 1-17 doi: 10.1590/SciELOPreprints. 756

González-Sanguino, C., Ausín, B., Castellanos, M. Á., Saiz, J., López, A., Ugidos, C., \& Muñoz, M. (2020). Mental health consequences during the initial stage of the 2020 Coronavirus pandemic (COVID-19) in Spain. Brain, Behavior, and Immunity, 87, 172-176. doi: 10.1016/j.bbi.2020.05.040

Gutiérrez Mercado, R. (2020). Propuesta de atención para los servicios de psicoterapia en línea (telepsicoterapia) derivados del Covid-19 en México. Psicología y Salud, 30(1), 133-136. doi: 10.25009/pys.v30i1.2640

Gutiérrez Zúñiga, C., \& de la Torre, R. (2020). COVID-19: la pandemia como catalizador de la videogracia. Espiral Estudios Sobre Estado y Sociedad, 27(7879), 167-213. doi: 10.32870/eees.v28i78-79.7205

Guzmán Bohórquez, L. D., Duarte Ramos, Y., \& Giraldo Camacho, M. A. (2019) Diferencia en los niveles de empatía entre hombres y mujeres: Una revisión bibliográfica (Tesis de grado-pregrado). Barrancabermeja, Santander: Universidad Cooperativa de Colombia. Retrieved from https://repository.ucc. edu.co/bitstream/20.500.12494/15756/1/2019_estudiantes_genero_conducta.pdf

Hu, L., \& Bentler, P. M. (1999). Cutoff criteria for fit indexes in covariance structure analysis: Conventional criteria versus new alternatives. Structural Equation Modeling: Multidisciplinary Journal, 6(1), 1-55. doi: 10.1080/10705519909540118 
Instituto Nacional de Estadística y Geografía [INEGI]. (2020). Censo de Población y Vivienda 2020 - Religión. Retrieved from https://www.inegi.org.mx/temas/ religion/

Johnson, M. C., Saletti-Cuesta, L., \& Tumas, N. (2020). Emociones, preocupaciones y reflexiones frente a la pandemia del COVID-19 en Argentina. Ciência \& Saúde Coletiva, 25(Supl 1), 2447-2456. doi: 10.1590/1413-81232020256.1.10472020

Kelm, Z., Womer, J., Walter, J. K., \& Feudtner, C. (2014). Interventions to cultivate physician empathy: a systematic review. BMC Medical Education, 14, 219. doi: 10.1186/1472-6929-14-219

Keyes, C. L. M. (2006). Subjective well-being in mental health and human development research worldwide: An introduction. Social Indicators Research, 77(1), 1-10. doi: 10.1007/s11205-005-550-3

Kline, R. B. (2015). Principles and practice of structural equation modeling. New York, NY: Guilford Publications. Retrieved from https://books.google.es/boo $\mathrm{ks}$ ?hl=es\&lr=\&id=Q61ECgAAQBAJ\&oi=fnd\&pg=PP1\&dq=Principles + and + practice + of + structural + equation + modeling $\&$ ots $=j F g f 0$ pwekh\&sig $=x$ FMhjze $\mathrm{q} 8 \ln E$ miS_H8PKILx4OQ\#v=onepage \&q=Principles $\% 20$ and $\% 20$ practice $\% 20$ of $\% 20$ structural $\% 20$ equation $\% 20$ modeling $\& \mathrm{f}=$ false

Landa Blanco, M., Landa Blanco, A. L., \& Cruz Murcia, R. (2018). Empatía, bienestar subjetivo y creencias religiosas en estudiantes de pregrado de la Universidad Nacional Autónoma de Honduras (pp. 1-17). Retrieved from https://ssrn.com/abstract $=3242518$

Liu, N., Zhang, F., Wei, C., Jia, Y., Shang, Z., Sun, L., ... Liu, W. (2020). Prevalence and predictors of PTSS during COVID-19 outbreak in China hardest-hit areas: Gender differences matter. Psychiatry Research, 287, 112921. doi: 10.1016/j. psychre.2020.112921

Mazza, C., Ricci, E., Biondi, S., Colasanti, M., Ferracuti, S., Napoli, C., \& Roma, P. (2020). A Nationwide Survey of Psychological Distress among Italian People during the COVID-19 Pandemic: Immediate Psychological Responses and Associated Factors. International Journal of Environmental Research and Public Health, 17(9), 3165. doi: 10.3390/ijerph17093165

Moral de la Rubia, J., \& Meza Peña, C. (2012). Evaluaciones de las funciones del yo en mujeres mexicanas con obesidad. Cuadernos de Medicina Psicosomática y Psiquiatría de Enlace, 102, 11-23. Retrieved from https://dialnet.unirioja.es/ servlet/articulo?codigo $=4393194$

Morales Chainé, S., López Montoya, A., Bosch Maldonado, A., Beristain Aguirre, A., Robles García, R., López Rosales, F., \& Fernández-Cáceres, C. (2020). Condiciones de salud mental durante la pandemia por COVID-19. Revista Internacional de Investigación en Adicciones, 6(2), 11-24. doi: 10.28931/ riiad.2020.2.03

Navarro Madera, J. M., \& Becerra Castellón, M. E. (2020). COVID-19: una mirada a la salud mental de la población de Tepic durante el confinamiento. Reflexiones Nayaritas en Salud Mental, 1(1), 48-63. Retrieved from https:// ceies.org/wp-content/uploads/2020/11/COVID-19-UNA-MIRADA-A-LASALUD-MENTAL-DE-LA-POBLACI\%C3\%93N-DE-TEPIC-DURANTEEL-CONFINAMIENTO.pdf

Nguyen, H. C., Nguyen, M. H., Do, B. N., Tran, C. Q., Nguyen, T. T. P., Pham, K. M., ... Duong, T. V. (2020). People with suspected COVID-19 symptoms were more likely depressed and had lower health-related quality of life: The potential benefit of health literacy. Journal of Clinical Medicine, 9(4), 965. doi: 10.3390/ jcm9040965

Ovejero Bruna, M., \& Cardenal Hernáez, V. (2015). Las fortalezas humanas desde la perspectiva de género: Un estudio exploratorio en población española. Revista Mexicana de Investigación en Psicologia, 7(2), 72-92. Retrieved from http:// revistamexicanadeinvestigacionenpsicologia.com/index.php/RMIP/article/ view/203

Peterman, A. H., Fitchett, G., Brady, M. J., Hernandez, L., \& Cella, D. (2002). Measuring spiritual well-being in people with cancer: The functional assessment of chronic illness therapy-spiritual well-being scale (FACIT-Sp). Annals of Behavioral Medicine, 24(1), 49-58. doi: 10.1207/s15324796abm2401 06

Qiu, J., Shen, B., Zhao, M., Wang, Z., Xie, B., \& Xu, Y. (2020). A nationwide survey of psychological distress among Chinese people in the COVID-19 epidemic: implications and policy recommendations. General Psychiatry, 33(2), e100213. doi: 10.1136/gpsych-2020-100213

Retuerto Pastor, A. (2004). Diferencias en empatía en funciones de las variables género y edad. Apuntes de Psicología, 22(3), 323-339. Retrieved from https:// core.ac.uk/download/pdf/196609339.pdf

Rivera-Ledesma, A., \& Montero, M. (2005). Espiritualidad y religiosidad en adultos mayores mexicanos. Salud Mental, 28(6), 51-58.

Rodríguez-Morales, A. J., Sánchez-Duque, J. A., Hernández Botero, S., Pérez-Díaz, C. E., Villamil-Gómez, W. E., Méndez, C. A., ... Paniz-Mondolfi, A. (2020). Preparación y control de la enfermedad por coronavirus 2019 (COVID-19) en América Latina. Acta Médica Peruana, 37(1), 3-7. doi: 10.35663/ amp.2020.371.909

Román Mella, F., Vinet, E. V., \& Alarcón Muñoz, A. M. (2014). Escalas de Depresión, Ansiedad y Estrés (DASS-21): Adaptación y propiedades psicométricas en estudiantes secundarios de Temuco. Revista Argentina de Clínica Psicológica, 23(2), 179-190. Retrieved from https://www.redalyc.org/ pdf/2819/281943265009.pdf

Ryan, R. M., \& Deci, E. L. (2001). On happiness and human potentials: A Review of Research on Hedonic and Eudaimonic Well-Being. Annual Review of Psychology, 52, 141-166. doi: 10.1146/annurev.psych.52.1.141

Salgado, A. C. (2014). Revisión de estudios empíricos sobre el impacto de la religión, religiosidad y espiritualidad como factores protectores. Propósitos y Representaciones, 2(1), 121-159. doi: 10.20511/pyr2014.v2n1.55

San Martín Ahumada, P. (2020). Efectos del aislamiento social y la cuarentena sobre el bienestar subjetivo de los chilenos durante el brote de COVID-19. SciELO Preprints - Section: Health Sciences, 1-10. doi: 10.1590/SciELOPreprints.368

Sandín, B., Valiente, R. M., García-Escalera, J., \& Chorot, P. (2020). Impacto psicológico de la pandemia de COVID-19: Efectos negativos y positivos en población española asociados al periodo de confinamiento nacional. Revista de Psicopatología y Psicología Clínica, 25(1), 1-22. doi: 10.5944/rppc.27569

Sosa Correa, M., \& Duarte Briceño, E. (2004). Creatividad y funciones del Yo como fortalezas para el desarrollo humano. Educación y Ciencia, 8(15), 101-117. Retrieved from https://www.researchgate.net/profile/Efrain-Duarte-Briceno/ publication/279682965_Creatividad_y_funciones_del_Yo_como_fortalezas _ para_el_desarrollo_humano/links/55c296a808aeb975673e469b/Creatividad-yfunciones-del-Yo-como-fortalezas-para-el-desarrollo-humano.pdf

Ubillos Landa, S., González Castro, J. L., Puente Martínez, A., \& Gracia Leiva, M. (2020). Afrontando el impacto del COVID-19. Resultados preliminares III (pp. 1-37). Universidad de Burgos. Retrieved from https://fundadeps.org/wpcontent/uploads/2020/10/Afrontando_el_impacto_del_COVID19-3.pdf

Vera-Villaroel, P. (2020). Psicología y COVID-19: Un análisis desde los procesos psicológicos básicos. Cuadernos de Neuropsicolología / Panamerican Journal of Neuropsychology, 14(1), 10-18. doi: 10.7714/CNPS/14.1.201

Wang, C., Pan, R., Wan, X., Tan, Y., Xu, L., Ho, C. S., \& Ho, R. C. (2020). Immediate Psychological Responses and Associated Factors during the Initial Stage of the 2019 Coronavirus Disease (COVID-19) Epidemic among the General Population in China. International Journal of Environmental Research and Public Health, 17(5), 1729. doi: 10.3390/ijerph17051729

Zinnbauer, B. J., Pargament, K. I., \& Scott, A. B. (1999). The emerging meanings of religiousness and spirituality: Problems and prospects. Journal of Personality, 67(6), 889-919. doi: 10.1111/1467-6494.00077 